\author{
KAMIL RUDOL ${ }^{1}$
}

\title{
Funkcje wspólnot gruntowych w świetle badań empirycznych
}

Instytucja wspólnoty gruntowej w Polsce wywodzi się bezpośrednio ze średniowiecznej instytucji tzw. własności podzielonej według treści (dominium divisum). Występowała ona na ziemiach polskich do XIX wieku, tj. do czasów uwłaszczenia włościan ${ }^{2}$. Według tej konstrukcji, grunt stanowił jednocześnie przedmiot własności dwóch właścicieli, tzn. właściciela zwierzchniego (dominus eminens lub dominus directus), któremu przysługiwała tzw. własność zwierzchnia (dominium eminens lub dominium directum), oraz właściciela użytkowego (dominus utilis), któremu przysługiwała tzw. własność użytkowa (dominium utile) ${ }^{3}$. Właścicielowi użytkowemu (lennikowi) przysługiwało prawo bezpośredniego użytkowania gruntu, zaś właścicielowi zwierzchniemu (seniorowi) - prawo do pobierania od właściciela użytkowego czynszu ${ }^{4}$. Nie był to jedynie obligacyjny stosunek dzierżawy, gdyż oba rodzaje własności, tzn. zarówno własność zwierzchnia, jak i własność użytkowa, obejmowały prawo do rzeczy własnej, a nie cudzej. Treść prawa własności dzieliła się zatem pomiędzy dwóch właścicieli, skąd zaczerpnięty został termin „własność podzielona według treści"'.

1 Instytut Nauk Prawnych Polskiej Akademii Nauk.

2 Pierwsze wspólnoty gruntowe wydzielano jako grunty do wspólnego użytkowania włościan i dziedzica w czasie zakładania wsi na prawie magdeburskim (niemieckim) w XIII i XIV w. (zob. F. Bujak, Studia nad osadnictwem Małopolski, Kraków 1905; J. Buzek, Administracja gospodarstwa społecznego, Warszawa 1913, s. 67; Z. Ludkiewicz, Polityka agrarna, Poznań-Warszawa 1921, s. 215). Niektóre z nich zostały utworzone także w drodze przywilejów nadanych przez królów polskich i możnowładców, w tym m.in. nadana przez Kazimierza Wielkiego przywilejem z roku 1348 oraz potwierdzana następnie przez Zygmunta Starego, Stefana Batorego, Michała Korybuta Wiśniowieckiego, Jana Sobieskiego, Augusta II Sasa, Augusta III i Stanisława Augusta Poniatowskiego wspólnota leśna „Piwniczna Szyja”. Podstawowa i najliczniejsza grupa wspólnot gruntowych powstała jednak w połowie XIX wieku w czasie uwłaszczenia chłopów oraz przy wykupie i regulacji służebności. W późniejszym okresie wspólnoty powstawały także przez nabywanie gruntów w celach wspólnego użytkowania (zob. K. Marciniuk, Kilka uwag do założeń projektu ustawy o zmianie ustawy o zagospodarowaniu wspólnot gruntowych, „Studia luridica Agraria" 2012, t. X, s. 535).

3 Zob. J. Ignatowicz, K. Stefaniuk, „Prawo rzeczowe” 2009, s. 119

4 Zob. R. Strzelczyk, Prawo Nieruchomości, Warszawa 2017, Legalis.

$5 \quad$ W nauce prawa rzymskiego podnosi się, że do opracowania konstrukcji własności podzielonej najbardziej przyczynił się Bartolus de Saxoferrato - twórca sformułowanej w połowie XIV w. definicji własności (dominium), rozumianej jako jednolite prawo dowolnego dysponowania rzeczą materialną, chyba że zabrania tego ustawa (ius de re corporali perfecte disponendi nisi lex prohibeat) (zob. W. Dajczak, T. Giaro, F. Longchamps de Bérier, Prawo rzymskie, Warszawa 2015, s. 370-372, 414.). 
Konstrukcja własności podzielonej, pomijając marginalne wyjątki, nie ostała się ani na ziemiach polskich, ani też na obszarze Europy Zachodniej. Na terenie odrodzonego państwa polskiego przeprowadzono w XIX wieku proces uwłaszczenia włościan, polegający na likwidacji własności podzielonej przez przyznanie dotychczasowym właścicielom użytkowym jednolitego prawa własności ${ }^{6}$. W procesie tym ujawniło się trudne do rozwiązania zagadnienie prawne, związane z gruntami stanowiącymi wspólną własność użytkową wielu osób, często stanowiących całą jednostkę osadniczą, taką jak wieś, zaścianek, osiedle czy miasto ${ }^{7}$. Problem ten rozwiązywano na dwa sposoby. Albo poprzez przyznanie jednolitej własności gruntu jednemu z dotychczasowych współwłaścicieli użytkowych, z jednoczesnym ustanowieniem służebności gruntowych na rzecz pozostałych dotychczasowych współwłaścicieli użytkowych, albo też przez pozostawienie gruntu we wspólnocie przysługującej mieszkańcom danej jednostki osadniczej. W ten sposób powstała swoista konstrukcja prawna, współcześnie określana mianem wspólnoty gruntowej ${ }^{8}$.

Wspólnoty gruntowe poddawane były skrajnie różnym regulacjom prawnym, których aksjologia uzasadniona była nastrojami danego momentu dziejowego. Było to przede wszystkim wynikiem dokonujących się stale pewnych przewartościowań celów, jakie w zależności od poziomu industrializacji kraju, stopnia zamożności społeczeństwa czy struktury zawodowej ludności, stawiano przed wspólnotami. Funkcja normatywna współcześnie obowiązującej ustawy z dnia 29 czerwca 1963 r. o zagospodarowaniu wspólnot gruntowych ${ }^{9}$ była uzasadniona założeniami polityki rolnej okresu tzn. socjalizacji pośredniej ${ }^{10} \mathrm{i}$ miała charakter stricte gospodarczy ${ }^{11}$. Wskazać należy, że ustawodawca ze świadomością przyjął metodę jednorazowego ukształtowania praw do korzystania z nieruchomości wspólnotowych, upoważniając do udziału jedynie rolników faktycznie korzystających z tych gruntów oraz zakazując ich podziału na działki indywidualne. Jednocześnie, zobowiązał on udziałowców do zespołowego zagospodarowania nieruchomości zaliczanych w skład przedstawianej instytucji, nakładając obowiązek powołania w tym celu spółki oraz umożliwiając organom administracji jej powołanie w trybie przymusowym ${ }^{12}$.

Zob. J. Bardach, B. Leśnodorski, M. Pietrzak, Historia ustroju i prawa polskiego, Warszawa 2009, s. 421-425; T. Łepkowski, Polska - narodziny nowoczesnego narodu, 1764-1870, Warszawa 1967, s. 58.

8 Oba przedstawione wyżej rozwiązania miały jednak charakter niedoskonały. Stosowano je głównie ze względów pragmatycznych, gdyż pozwalały na stosunkowo szybką i bezkonfliktową likwidację niechcianej już własności podzielonej (Zob. R. Strzelczyk, op. cit.).

9 Dz.U. z 1963 r., nr 28, poz. 169.

10 Zob. A. Stelmachowski, Prawo rolne, Warszawa 1987, s. 91-92.

11 Jak wynika z treści referatu Biura Politycznego KC na XII Plenum KC PZPR, wspólnoty gruntowe stanowiły poważną rezerwę produkcyjną rolnictwa o nieuregulowanych stosunkach własnościowych, których grunty nie były objęte prawidłową i racjonalną gospodarką. Dlatego też powołana powyżej ustawa, poprzez uregulowanie stosunków własnościowych analizowanych instytucji, miała na celu stworzenie instrumentów pozwalających na właściwe zarządzanie zaliczanymi do niej gruntami celem ich należytego wykorzystania rolniczego (zob. „Trybuna Ludu" 1963, nr 58).

12 Widział on bowiem we wspólnotach gruntowych formę prostej kooperacji na wsi i wdrażania rolników do zespołowych form produkcji rolniczej (zob. M. Ptaszyk, Spółki do zagospodarowania wspólnot gruntowych - sytuacja 
Dokonanie się transformacji ustrojowej w Polsce po roku 1989, a następnie wstąpienie do Unii Europejskiej w dniu 1 maja 2004 r. na mocy Traktatu akcesyjnego ${ }^{13}$ skutkowało wprowadzeniem wielu zmian na gruncie prawo-politycznym, gospodarczym oraz społecznym, które zdezaktualizowały cele, jakie przyświecały prawodawcy w roku 1963. Zmianie uległa bowiem rola, jaką w zamyśle ustawodawcy pełnić miały wspólnoty gruntowe. Dezaktualizacji uległy ich funkcje normatywne, podając $\mathrm{w}$ wątpliwość przez część przedstawicieli doktryny prawa ${ }^{14}$ dalsze utrzymywanie analizowanych instytucji w systemie prawa polskiego.

Powyższa okoliczność zadecydowała o podjęciu tematyki niniejszego artykułu, którego celem jest konfrontacja pełnionych przezeń funkcji normatywnych z funkcjami rzeczywistymi. Dla osiągnięcia powyższego, podjęte zostały rozważania mające na celu umiejscowienie wspólnoty gruntowej w kontekście pro- środowiskowym, społeczno-gospodarczym oraz kulturowym. Podstawą przedmiotowych rozważań stał się całokształt wiadomości dotyczących analizowanej instytucji, prezentowanych $\mathrm{w}$ doktrynie i orzecznictwie, jak również wyniki przeprowadzonych badań empirycznych, uzyskanych w drodze sondażowego badania wybranych wspólnot gruntowych z różnych obszarów Polski ${ }^{15}$. Przedstawiana metoda badawcza polegała na pozyskaniu nazw, adresów oraz współrzędnych geograficznych charakteryzowanych instytucji za pomocą dwóch niezależnych metod informatycznych. Pierwsza z nich - w drodze iteracyjnego przeszukiwania mapy Google ${ }^{16}$; druga zaś - polegająca na przeszukaniu bazy danych z portalu KRS-ONLINE ${ }^{17}$. Po dokonaniu weryfikacji powtarzających się wyników z dwóch metod badawczych, otrzymanych zostało 385 unikalnych wyników ${ }^{18}$. Przy zastosowaniu doboru zbiorowości prób-

prawna, funkcjonowanie, perspektywy, Kraków 1989, s. 41)

13 Traktat ateński z dnia 16 kwietnia 2003 r. (Dz.U. z 2004 r. nr 90, poz. 864).

14 Zob. np. I. Lipińska, Rola i funkcjonowanie wspólnot gruntowych we współczesnych warunkach gospodarczych, „Problemy Rolnictwa Światowego” 2010, t. 10 (XXV), z. 4, s. 35-44.

15 Metoda sondażowa jest szeroko stosowanym rodzajem badań społecznej problematyki wsi i rolnictwa. Określa się ją jako badanie „reprezentatywne”, jako „sondaże ankietowe”, a w terminologii angielskiej jako „sample survey lub survey research”. Przedmiotem badań za pomocą sondażu są fakty, wydarzenia, opinie, postawy, cechy jednostek (zob. J. Turowski, Socjologia wsi i rolnictwa, Lublin 1995, s. 67).

16 Przedmiotowa metoda składała się z następujących czynności: interaktywna mapa Polski została podzielona na obszary o wielkości promienia 50 km (maksymalny parametr) w programie R przy użyciu biblioteki leaflet. Następnie, przy użyciu interfejsu programowania aplikacji (API) dostarczonego przez Google zostało złożone zapytanie dla każdego z obszarów o wyszukanie miejsca, zawierające słowa kluczowe „wspólnota” i „gruntowa”. Na tej podstawie otrzymanych zostało 1325 wyników. Następnie, po usunięciu duplikatów, a w konsekwencji pozostawieniu unikalnych wpisów, pozostały 63 wyniki, które naniesiono na mapę. Należy wskazać, że specyfikacja aplikacji Google automatycznie wyszukuje poza zadany obszar, dlatego też można mieć pewność, że zbadana została cała powierzchnia kraju, w zakresie ujawnionych na mapie Google wspólnot gruntowych.

17 Powołana metoda polegała na wyszukaniu na portalu haseł „wspólnota gruntowa”. Serwis bezpłatnie udostępnia informacje o podmiotach wpisanych do KRS oraz CEIDG na podstawie ustawy z dnia 20 sierpnia 1997 r. o Krajowym Rejestrze Sądowym (Dz.U. z 1997 r. nr 121, poz. 769 ze zm.) oraz ustawy z dnia 2 lipca 2004 r. o swobodzie działalności gospodarczej (Dz.U. z 2004 r. nr 173, poz. 1807 ze zm.). W drodze poszukiwania otrzymano nazwy, typy działalności oraz adresy wspólnot gruntowych w łącznej liczbie 207 wyników. Następnie, przy użyciu interfejsu programowania aplikacji (API) dostarczonego przez Google, na podstawie adresów ustalono współrzędne geograficzne, które naniesiono na mapę.

18 Należy w tym miejscu wskazać, że wyniki obejmujące miejsce położenia wspólnot gruntowych, otrzymane w drodze przeprowadzonych poszukiwań, statystycznie odpowiadają informacjom opublikowanym przez Najwyższą Izbę Kontroli. 
nej losowo-przestrzennej, korzystając z otrzymanych w ten sposób danych adresowych, wspólnot gruntowych skierowane zostało dwieście kwestionariuszy ankietowych ${ }^{19}$, na które odpowiedziało 26 wspólnot. W zakresie kolejnych 24 wspólnot gruntowych badanie przeprowadzone zostało $\mathrm{w}$ formie telekonferencji $\mathrm{w}$ oparciu o numery kontaktowe otrzymane od przedstawicieli przebadanych wspólnot ${ }^{20}$. Nadto, przeprowadzone zostały także dwa badania terenowe na obszarach Wspólnoty gruntowej „Góra” w Nowym Mieście nad Pilicą oraz Wspólnoty Gruntowej w Gąsawach Rządowych.

Biorąc pod uwagę liczbę przebadanych wspólnot gruntowych, wielkość populacji wskazywaną przez Najwyższą Izbę Kontroli oraz współczynniki poziomu ufności na poziomie $95 \%$ i wielkości frakcji na poziomie 0,5 , błąd maksymalny prezentowanych wyników badań zasady statystyki nakazują szacować na poziomie $14 \%$. Bezkrytyczne przyjęcie takiej wielkości pozwalałoby zatem twierdzić, że otrzymane wyniki co do zasady odzwierciedlają stanowisko wspólnot gruntowych na obszarze całego kraju w zakresie postawionych pytań. $Z$ drugiej jednak strony należy domniemywać, że fakt uzyskania jedynie 26 odpowiedzi spośród dwustu skierowanych kwestionariuszy oznacza w istocie, że znakomita większość analizowanych instytucji nie wykazała zainteresowania badaniem, nie funkcjonuje bądź też nie istnieje, zaś otrzymane odpowiedzi - jako pozyskane od niereprezentatywnej próby - mogą być niemiarodajne. Wobec powyższego, kierując się daleko posuniętą ostrożnością, należy odnosić otrzymane wyniki wyłącznie do sytuacji wspólnot gruntowych rzeczywiście funkcjonujących, jak również postrzegać je przez pryzmat zachęty do podejmowania działalności przez wspólnoty martwe, które w świetle znowelizowanych przepisów prawa mogą zostać powołane do życia.

Rozpoczynając rozważania od funkcji pro- środowiskowej wskazać należy, że współczesne europejskie podejście do rozwoju rolnictwa i obszarów wiejskich oparte jest na zgodnym łączeniu celów środowiskowych i ekonomicznych. Początki takiego postrzegania rozwoju, w krajach Unii Europejskiej, sięgają lat siedemdziesiątych XX wieku. Pojawiło się ono jako odpowiedź na problemy wywołane rozwojem wsi według paradygmatu rolno-industrialnego produktywizmu ${ }^{21}$. Przy-

Projektowane pytania odnosiły się do kwestii ustrojowych wspólnoty, a także kładły nacisk na praktyczne aspekty jej funkcjonowania, w szczególności - korzyści i problemy z tym związane. Należy podkreślić, że uzyskane w ten sposób odpowiedzi są szczególnie istotne w świetle wprowadzonych przez ustawodawcę przepisów nowelizacyjnych, umożliwiających likwidację wspólnoty gruntowej.

O ile jednak kwestionariusze ankietowe zawierały oświadczenie o wyrażeniu zgody na publikacje danych dla celów naukowych, o tyle forma telefoniczna uniemożliwiła pozyskanie takiego oświadczenia. Dlatego też tak otrzymane wyniki badań uwzględnione zostały w zakresie statystycznym, jednak ich treść nie zostanie odniesiona do konkretnych przykładów wspólnot gruntowych.

21 Rozwój według tego paradygmatu miał wszechstronny wpływ nie tylko na rolnictwo, ale również na ogólny rozwój cywilizacyjny, uwidaczniając się na jego różnych płaszczyznach. W konsekwencji prowadził do niekontrolowanego rozwoju gospodarczego, wzrastającego zanieczyszczenia i degradacji środowiska naturalnego oraz pojawiania się wielu problemów społeczno-gospodarczych. Bardzo niekorzystnym zjawiskiem dla rozwoju rolnictwa według modelu industrialnego jest sprowadzanie celu gospodarowania wyłącznie do maksymalizacji korzyści ekonomicznych (zysku) i skupianie się na intensyfikacji produkcji za wszelką cenę, nie uwzględniając 
czyną wprowadzenia w Polsce nowego podejścia do rozwoju były natomiast niekorzystne zjawiska gospodarcze, które pojawiły się w gospodarce okresu transformacji systemu społeczno-ekonomicznego i przygotowań do członkostwa w Unii Europejskiej. Celem nowej, europejskiej koncepcji rozwoju wsi (obszarów wiejskich) jest rozwój zrównoważony, w którym dąży się jednocześnie do poprawy warunków życia ludności i prowadzenia działalności gospodarczej na obszarach wiejskich, przy nienaruszaniu przy tym specyficznych zasobów wsi, do których zalicza się m.in. środowisko naturalne oraz krajobraz wsi ${ }^{22}$. Koncepcja zrównoważonego rozwoju wsi zakłada wypełnianie zarówno przez rolnictwo, jak i przez obszary wiejskie, różnych funkcji rolniczych i pozarolniczych, które w Polsce, począwszy od lat 90., ulegają znaczącemu poszerzeniu. Jednocześnie, następuje wyraźne zmniejszanie znaczenia pierwotnej funkcji rolnictwa jako producenta żywności i surowców rolniczych, a wzrost znaczenia innych funkcji, w tym w szczególności środowiskowej. Wynika to z coraz większej świadomości społeczeństwa o istniejących zagrożeniach ze strony środowiska naturalnego i z rosnących wymagań w zakresie jakości żywności i środowiska ${ }^{23}$. Koncepcja zrównoważonego rozwoju jest obecnie ,konstytucyjną normą rozwoju Polski, obowiązującą we wszystkich obszarach gospodarki i wszelkich płaszczyznach strategicznego planowania"24.

Z przywołaną powyżej koncepcją koresponduje przebadana próba wspólnot gruntowych, gdyż - jak wskazują wyniki badań empirycznych - ich zagospodarowanie odpowiada zasadom rolnictwa zrównoważonego. Ze względu na ich charakter prawny, objawiający się wielością podmiotów korzystających z gruntów wspólnotowych, na tych obszarach, gdzie uprawiane jest rolnictwo ${ }^{25}$, ma ono zasadniczo charakter ekstensywny, charakteryzujący się o wysokich nakładach pracy i niskich

przy tym ograniczeń środowiskowych i stanu odnawialnych zasobów naturalnych, traktując je jako dobra wolne. Takie podejście do rozwoju prowadziło do zachwiania równowagi ekologicznej, czego skutki objawiają się zanieczyszczeniem wód, powietrza, degradacją gleb oraz niekorzystnymi zmianami w krajobrazie. Ponadto, zbyt intensywne (skupiające się wyłącznie na maksymalizacji zysku z jednostki powierzchni) wykorzystywanie w przeszłości użytków rolnych spowodowało ich erozję wodną i wietrzną, znaczący wzrost zakwaszenia i zmniejszenie zawartości próchnicy w glebach oraz drastyczny wzrost zanieczyszczeń toksycznymi związkami chemicznymi. Dostrzeżenie licznych ograniczeń i zagrożeń dalszego rozwoju rolnictwa, związanych z gospodarowaniem według industrialnej formuły, sprawiło, że ważną kwestią stało się zrównoważenie jego rozwoju. Takim „antidotum” stała się powszechnie współcześnie akceptowana koncepcja zrównoważonego rozwoju, będąca europejskim paradygmatem teorii rozwoju oraz konstytucyjną normą rozwojową, obowiązującą we wszystkich obszarach polskiej gospodarki (zob. B. Roszkowska-Mądra, Kategorie ekonomii zrównoważonego rozwoju na poziomie gospodarstwa rolnego, (w:) B. Poskrobko, Ekonomia zrównoważonego rozwoju w świetle kanonów nauki, Białystok 2011, s. 157-158).

22 Zob. B. Roszkowska-Mądra, Kategorie ekonomii zrównoważonego rozwoju na poziomie gospodarstwa rolnego, „Gospodarka Narodowa” 2009, nr 10, s. 83.

23 Zob. J. Zegar, Programowanie ekorozwoju obszarów wiejskich, (w:) P. Jeżowski, Zarządzanie w sektorze publicznym-rozwój zrównoważony - metody wyceny, Warszawa 2002, s. 87-111.

24 Zob. M. Adamowicz, Wielofunkcyjne gospodarstwa rolne jako podmiot w rozwoju wsi i rolnictwa, „Prace Naukowe SGGW” 2004, nr 33; M. Adamowicz, Wiejskie gospodarstwa domowe w obliczu problemów transformacji, integracji i globalizacji, Warszawa 2004, s. 239-257.

25 Inne sposoby wykorzystywania nieruchomości zaliczanych do wspólnot gruntowych przedstawione zostaną w dalszej części niniejszego rozdziału. 
kosztach. Przedstawiciele ponad $70 \%$ przebadanych wspólnot gruntowych jednomyślnie wskazują, że grunty te wykorzystywane są odpowiednio dla celów wspólnej bądź indywidualnej uprawy rolnej ${ }^{26}$, wypasania i hodowli bydła, owiec oraz innego inwentarza ${ }^{27}$, jak również korzystania z zasobów naturalnych. To ostatnie polega zaś najczęściej na zbieraniu grzybów, runa czy chrustu w lasach ${ }^{28}$, wyrębie drzewa opałowego i budowlanego zgodnie z planami urządzenia lasu ${ }^{29}$, czy też koszeniu ląk i zbiorze trawy ${ }^{30}$. Podkreśla się przy tym, że korzystanie z gruntów wspólnoty we wskazany powyżej sposób odbywa się zgodnie z wymogami ochrony środowiska, zaś pozyskane płody rolne stanowią jedynie uzupełnienie, a nie zamienniki dla prowadzonych przez udziałowców wspólnot prywatnych gospodarstw rolnych ${ }^{31}$. Ponadto należy podkreślić, iż grunty zaliczane do wspólnot utrzymywane są w dobrej kulturze rolnej, a pobrane zasoby naturalne nierzadko bywają następnie odnawiane przez członków wspólnoty gruntowej”32.

W tym miejscu trzeba wskazać, że akceptując stanowisko o potrzebie harmonizacji celów produkcyjnych oraz celów ekologicznych w programach wspólnej polityki rolnej ${ }^{33}$, a także $w$ regulacjach prawnych wdrażających te programy, współczesne regulacje unijne wyraźnie akcentują realizację funkcji ochrony środowiska, co zostało w nauce określone jako „ekologizacja” prawa rolnego ${ }^{34}$. Począwszy od Agendy $2000^{35}$ mamy obecnie do czynienia z trzecim już okresem budżetowym UE

Zob. np. ankieta sporządzona przez przewodniczącego spółki dla zagospodarowania Wspólnoty Gruntowej w Sieradzu Osiedla Zapusta Wielka.

27 Zob. np. ankieta sporządzona przez przewodniczącego zarządu spółki dla zagospodarowania Wspólnoty Gruntowej wsi Radoszyce.

28 Zob. np. ankieta sporządzona przez przewodniczącego zarządu spółki dla zagospodarowania Wspólnoty LeśnoGruntowej w Siewierzu.

29 Zob. np. ankieta sporządzona przez przewodniczącego zarządu Wspólnoty Leśno-Gruntowej „Nadzieja” w Mierzęcicach, ankieta sporządzona przez przewodniczącego zarządu Wspólnoty Gruntowej wsi Raniżów.

Zob. np. ankieta sporządzona przez przewodniczącego zarządu spółki dla zagospodarowania Wspólnoty Gruntowej „Bania” w Płońsku. Zob. np. ankieta sporządzona przez przewodniczącego zarządu spółki Wspólnoty Gruntowej wsi Radoszyce. Jak wskazał przewodniczący zarządu Wspólnoty Gruntowej w Wikucicach Dużych, „wspólnota dokonuje również nasadzeń lasu i jego ochrony. Przykładowo, w 2014 r. wspólnota obsadziła 3 hektary sadzonkami sosny (zob. ankieta sporządzona przez przewodniczącego zarządu Wspólnoty Gruntowej w Wikucicach Dużych). Wspólna polityka rolna to polityka jednolitego funkcjonowania, wspierania i ochrony sektora rolnego w państwach członkowskich Unii Europejskiej. Zasady i cele WPR określone w Traktacie rzymskim z dnia 25 marca 1957 r., ustanawiającym Europejską Wspólnotę Gospodarczą (TEWG), zostały przejęte przez uregulowania obecnie obowiązującego TfUE. Zgodnie z art. 39 TfUE, celami wspólnej polityki rolnej są: a) zwiększenie wydajności rolnictwa przez wspieranie postępu technicznego, racjonalny rozwój produkcji rolnej, jak również optymalne wykorzystanie czynników produkcji, b) zapewnienie w ten sposób odpowiedniego poziomu życia ludności wiejskiej, zwłaszcza przez podniesienie indywidualnego dochodu osób pracujących w rolnictwie, c) stabilizacja rynków, d) zagwarantowanie bezpieczeństwa dostaw, e) zapewnienie rozsądnych cen w dostawach dla konsumentów. (zob. S. Prutis, Ochrona środowiska za pomocą instrumentów prawno-finansowych Wspólnej Polityki Rolnej, „Studia luridica Agraria” 2015, t. 13, s. 41-42). W doktrynie podkreśla się, że cele określone w art. 39 ust. 1 związane są przede wszystkim z krótkookresową polityką dochodową i rynkową, natomiast w ust. 2 art. 39 zawarto postanowienia stanowiące podstawę długookresowej polityki strukturalnej, choć oczywiście polityki te są ze sobą wzajemnie powiązane (zob. A. Jurcewicz, Prawo i polityka rolna Unii Europejskiej, Warszawa 2010, s. XXVI-14 i n.).

34 Zob. R. Budzinowski, (w:) P. Czechowski, Prawo rolne, Warszawa 2015, s. 29.

35 Agenda 2000 to zbiorcze, hasłowe określenie programu reform WPR, zaprojektowanych, wdrażanych i korygowanych na kanwie tzw. raportu Fischlera. Reforma ta zakładała dalsze urynkowienie rolnictwa, wzmocnienie jego konkurencyjności na rynkach światowych, jak również kontynuowanie rozwoju strukturalnego i ekologicz- 
obejmującym lata 2014-2020. Czasokresy poprzednie to lata 2000-2006 oraz lata 2007-2013. W każdym z okresów obowiązywały stosowne, wzajemnie zintegrowane regulacje prawne, określające zasady i warunki dostarczenia rolnictwu środków finansowych, w formie systemu wsparcia bezpośredniego lub systemu wsparcia rozwoju obszarów wiejskich. Wśród warunków wsparcia finansowego istotne miejsce zajmowały zawsze wymagania dotyczące ochrony środowiska, formułowane jako zachęty do działań proekologicznych, podejmowania dobrowolnych zobowiązań, czy też nakładane jako obowiązki publicznoprawne. Cechą charakteryzującą zmiany jest stopniowe narastanie wymagań ekologicznych, a w konsekwencji zwiększanie zakresu obowiązków w tym obszarze ${ }^{36}$. Aktualne, ustanowione na okres 20142020, instrumenty finansowo-prawne wspólnej polityki rolnej usystematyzowane ${ }^{37}$ zostały w trzech podstawowych rozporządzeniach Parlamentu Europejskiego i Rady (UE), przyjętych w dniu 17 grudnia 2013 r.: nr 1305/2013 w sprawie wsparcia rozwoju obszarów wiejskich przez Europejski Fundusz Rolny na rzecz Rozwoju Obszarów Wiejskich (EFRROW), nr 1306/2013 w sprawie finansowania wspólnej polityki rolnej, zarządzania nią i monitorowania jej oraz nr 1307/2013 ustanawiającym przepisy dotyczące płatności bezpośrednich na podstawie systemów wsparcia w ramach wspólnej polityki rolnej ${ }^{38}$.

Zestawiając powołane powyżej wyniki badań empirycznych, jak również założenia programowe wspólnej polityki rolnej należy stwierdzić, iż sposób zagospodarowania większości z przebadanych wspólnot gruntowych wpisuje się we współczesną tendencję ekologizacji wspólnej polityki rolnej. Sposób korzystania z gruntów zaliczanych w skład wybranych wspólnot gruntowych związany jest z poczuciem odpowiedzialności za wspólne otoczenie, jakie, co do zasady, posiadają uprawnieni do udziału w tych wspólnotach. Ponadto, eksploatacja zasobów wspólnoty nie przekracza tempa ich odnowy, zaś ilość zanieczyszczeń dostarczanych do otoczenia wskutek jej działalności jest mniejsza niż potencjał absorpcyjny środowiska. W konsekwencji, uczestnicy przebadanych instytucji nie tylko zapewniają ciągłość zagospodarowania gruntów wchodzących w jej skład, ale również dokonują tego w zgo-

nego obszarów wiejskich. Polityka Unii w sektorze rolnictwa miała zatem służyć wzmocnieniu ochrony środowiska naturalnego i rozwoju regionalnego. Reforma podkreślała znaczenie polityki rozwoju obszarów wiejskich i polityki ochrony środowiska w ramach WPR, a także zwiększenie bezpieczeństwa i jakości produktów rolnych. W konsekwencji przeglądu skuteczności Agendy 2000, na szczycie w Luksemburgu w 2003 roku Rada UE przyjęła dokument przewidujący wprowadzenie dalszych zmian w polityce rolnej na lata 2004-2013; zmiany polegały m.in. na uzależnieniu otrzymywania wsparcia przez rolnika od przestrzegania przez niego określonych standardów w zakresie ochrony środowiska naturalnego, właściwego traktowania zwierząt i bezpieczeństwa żywności (zob. szerzej A. Jurcewicz, Ewolucja Wspólnej Polityki Rolnej, (w:) P. Czechowski, Prawo rolne, Warszawa 2015, s. 100 i n.)

36 Zob. S. Prutis, Ochrona środowiska..., op. cit., s. 44.

37 Zob. szerzej D. Milanowska, Wybrane metody systematyzacji prawodawstwa Unii Europejskiej z uwzględnieniem aktów prawnych z zakresu prawa rolnego, „Studia luridica Agraria” 2013, t. XI, s. 11-23.

38 Rozporządzenia weszły w życie w dniu 20 grudnia 2013 r. - w dniu ich opublikowania w Dzienniku Urzędowym Unii Europejskiej L 347, s. 487, 549, 608. 
dzie z zasadami ochrony środowiska, wpisując się jednocześnie w ideę rolnictwa zrównoważonego ${ }^{39}$.

Problematykę występowania wspólnot gruntowych z punktu widzenia społeczno-gospodarczego wyjaśnia się poprzez zestawienie ze sobą dwóch kategorii: stanu posiadania ${ }^{40}$ i reżimu własności ${ }^{41}$. W zapoczątkowanych w połowie XVIII wieku dyskursach uzasadniających utrzymywanie wspólnot gruntowych, albo uznaje się stan posiadania za przyczynę reżimu wspólnotowego, albo wskazuje, że to właśnie przedmiotowy rezim był odpowiedzialny za ten $\operatorname{stan}^{42}$.

W pierwszym ujęciu wspólnoty gruntowe traktowane są jako nierozerwalnie związane z gruntami złej jakości. Wskazuje się, że przedstawiane instytucje występują najczęściej na obszarach wyjałowionych, oraz że jedynym zasadnym sposobem korzystania z tego typu gruntów jest wspólne korzystanie. Powyższe uzasadnione jest faktem, iż pozwalają one zarówno na podział ryzyk gospodarczych na obszarze wspólnoty, jak również umożliwiają uzupełnianie płodów pochodzących z prowadzonych gospodarstw rolnych zasobami pobranymi ze wspólnoty. Korzystanie z obszarów wspólnot odbywa się przy tym przy niskich kosztach pracy własnej, spełniając „,funkcję ubezpieczeniową” w stosunku do konkurencyjnej działalności rolników na terenach bardziej urodzajnych ${ }^{43}$. Przeciwnicy utrzymywania wspólnot gruntowych stoją na stanowisku, że reżim wspólnotowy ponosi odpowiedzialność za stan posiadania. Omawiane ujęcie podkreśla niską produktywność obszarów zaliczanych do analizowanej instytucji i uzasadniane jest zasadniczo poprzez występowanie tam tzw. efektu gapowicza ${ }^{44}$, tj. możliwości osiągania przez uprawnionych korzyści z tych gruntów w stopniu przewyższającym ich udział w kosztach

39 Konsekwencją realizacji przez wspólnoty gruntowe współczesnych założeń ekologizacji Wspólnej Polityki Rolnej jest możliwość jej partycypacji w programach wsparcia, w tym płatnościach za zazielenianie oraz w ramach działania rolnośrodowiskowo-klimatycznego oraz rolnictwa ekologicznego. Warunkiem otrzymania przedmiotowych płatności jest odpowiednio przestrzeganie przez jej uczestników praktyk rolniczych korzystnych dla klimatu i środowiska lub praktyk równoważnych, zachowanie oraz propagowane na gruntach wspólnoty zmian w praktykach rolnych mających pozytywny wkład w środowisko i klimat, jak również konwersja lub utrzymanie na tych obszarach praktyk i metod rolnictwa ekologicznego. Wskazać należy, że zgodnie ze stanowiskiem prezentowanym przez przeważającą część judykatury oraz doktryny prawa, legitymację do udziału w postępowaniach administracyjnych w tym przedmiocie ma spółka wspólnoty gruntowej (zob. I. Lipińska, Z prawnej problematyki wspólnot gruntowych, „Studia luridica Agraria” 2011, t. X, s. 207; J. Szachułowicz, Spółki grup producentów rolnych spółkami użyteczności publicznej, „Studia luridica Agraria” 2005, t. 5, s. 203; wyrok Wojewódzkiego Sądu Administracyjnego w Rzeszowie z dnia 24 listopada 2015 r., I SA/Rz 918/15, Lex). Prezentowane jest również jednak stanowisko przeciwne, przyznające takie uprawnienie wyłącznie rolnikom indywidualnie wykonującym powyższe zobowiązania na gruntach zaliczanych w skład wspólnoty (zob. wyrok Wojewódzkiego Sądu Administracyjnego w Warszawie z dnia 6 września 2006 r., IV SA/Wa 452/06, Lex).

40 Ang. State of the resource.

41 Ang. Property regime.

42 Zob. M. De Moor, P. Warde, L. Shaw-Taylor, The management of common land in north west Europe, c. 15001850, Turnhout 2002, s. 19.

43 Zob. R. Allen, Enclosure and the yeoman. The agricultural development of the south Midlands 1450-1850, Oxford 1992; J.L. Hammond, B. Hammond, The village labourer 1760-1832, Gloucester 1911; J.M. Neeson, Commoners: common right, enclosure and social change in England 1700-1820, Cambridge 1993; R. Tawney, The Agrarian problem in the sixteenth century, London 1912, s. 234-280; E.P. Thompson, The making of the English working class, London 1968, s. 233-258; E.P. Thompson, Customs in common, London 1992, s. 97-184. 
wytworzenia. Powyższa teoria zakłada, że wspólne zagospodarowanie gruntów zaliczanych do charakteryzowanej instytucji nie może prowadzić do utrzymania ich produktywności, albowiem część osób uprawnionych do korzystania ze wspólnoty działać będzie wyłącznie na własną korzyść. Wskazuje się, że korzystanie z gruntów, na których „efekt gapowicza” jest możliwy, odbywać się będzie do czasu, kiedy wyczerpią się wszelkie zasoby ${ }^{45}$.

Odnosząc powyższe rozważania do wyników przeprowadzonych badań empirycznych zauważyć należy, iż w zależności od charakteru gruntów zaliczanych w skład wspólnoty gruntowej, są w zasadniczej większości ${ }^{46}$ wykorzystywane dla celów wspólnej uprawy rolnej, wypasania bydła oraz korzystania z zasobów naturalnych (np. zbierania drewna opałowego i budowlanego w lasach oraz traw na łąkach). Pozyskane w ten sposób płody rolne stanowią uzupełnienie dla prowadzonych przez udziałowców wspólnot prywatnych gospodarstw rolnych, zabezpieczając ich potrzeby produkcyjne ${ }^{47}$. Jak podkreślił $\mathrm{w}$ trakcie przeprowadzonego wywiadu przewodniczący zarządu spółki Wspólnoty Gruntowej „Góra” w Nowym Mieście nad Pilicą, „w sytuacji braku objęcia gruntów zarządem i zagospodarowaniem spółki wspólnoty gruntowej zostałyby one zdewastowane i pozbawione właściwości produkcyjnych".

Ponadto, w ponad $40 \%$ przebadanych wspólnot, część gruntów zaliczanych w ich skład jest przedmiotem dzierżawy samych udziałowców bądź osób trzecich, zaś środki uzyskane z czynszu przeznaczane są na cele statutowe lub społeczne. Przewodniczący zarządu spółki Wspólnoty Leśno-Gruntowej „Nadzieja” w Mierzęcicach wskazał, że „uzyskane z dzierżawy dla przedsiębiorstw środki finansowe przeznaczane są przez spółkę na potrzeby mieszkańców. W ten sposób w miejscowości położenia wspólnoty gruntowej wybudowane zostało Centrum Kulturalno-Rekreacyjne oraz budynek dla Ochotniczej Straży Pożarnej. Ponadto, z tych środków finansowanie otrzymują szkoły i przedszkola, koła gospodyń wiejskich czy też związki emerytów"48. W podobnym zakresie wypowiedział się przewodniczący spółki Wspólnoty Gruntowej w Gąsawach Rządowych, wskazując na następujące projekty społeczno-ekonomiczne realizowane przez wspólnotę: ,wybudowanie Publicznej Szkoły Podstawowej w Gąawach oraz jej doposażenie w sprzęt sportowy, przekazanie środków na wykonanie posadzki w kościele parafialnym, remont drogi gminnej w Gąsawach Rządowych-Niwach, uruchomienie programu budowy parkingu z kostki brukowej przed kościołem parafialnym, realizacja projektu segregacji śmieci - zakup 280 pojemników na odpady komunalne dla mieszkańców Gąsaw

\footnotetext{
45 Zob. D.C. North, R.P. Thomas, The first economic revolution, „Economic History Review” 1977, vol. 30, s. 229-241.

46 Tj. w ponad $75 \%$ przebadanych wspólnot.

47 Zob. np. ankieta sporządzona przez przewodniczącego zarządu spółki Wspólnoty Gruntowej wsi Radoszyce.

48 Zob. ankieta sporządzona przez przewodniczącego zarządu spółki Wspólnoty Leśno-Gruntowej "Nadzieja” w Mierzęcicach.
} 
Rządowych i Gąsaw Rządowych-Niw, otwarcie świetlicy wiejskiej dla mieszkańców obu wsi w Gąsawach Rządowych" ${ }^{\text {"9 }}$.

Niezależnie od wsparcia finansowego, funkcje społeczno-gospodarcze wybranych wspólnot gruntowych realizowane są poprzez przekazywanie w drodze darowizny bądź oddawane w nieodpłatne korzystanie gruntów wspólnoty na rzecz gmin w celach realizacji przez nie celów społecznie korzystnych. Z informacji otrzymanych od przewodniczącego zarządu spółki dla zagospodarowania Wspólnoty LeśnoGruntowej w Siewierzu wynika, iż „zarząd Spółki nieodpłatnie udostępnił teren pod budowę kanalizacji deszczowej i komunalnej na Osiedlu Zachód oraz na zorganizowanie tzw. ścieżki ekologicznej. Ponadto, zarząd za symboliczną opłatą udostępnił Gminie Siewierz teren na ułożenie kilkuset metrów wodociągu, jak również wyraził zgodę na nieodpłatne korzystanie z jej terenów na ułożenie sieci światłowodowej na terenie miasta ${ }^{50}$. Przewodniczący Zarządu Wspólnoty Gruntowej wsi Strzałków wskazał natomiast, iż „na obszarze wspólnot znajdują się m.in. wielofunkcyjne boisko sportowe, park im. ks. Stefana Korala oraz plac zabaw. Boisko służy do zajęć z kultury fizycznej uczniom pobliskiej szkoły podstawowej, organizacji imprez i zawodów sportowych. Park jest miejscem wypoczynku i organizacji imprez. Plac zabaw służy zaś najmłodszym mieszkańcom wsi. Ponadto, zbiorniki wodne są użytkowane przez funkcjonujące koła wędkarskie" ${ }^{51}$.

W świetle powyższego należy wnioskować, że dla wybranych społeczności lokalnych, na obszarze których wspólnoty zostały powołane i funkcjonują w zgodzie z przepisami ustawy, przedmiotowe instytucje nie utraciły swojego znaczenia gospodarczego. Niezmiennie bowiem służą zorganizowaniu współdziałania między rolnikami indywidualnymi ze względu na potrzeby należytego wykorzystania określonych obiektów produkcyjnych ${ }^{52}$. Ponadto, współczesny model wykorzystania gruntów wspólnoty poprzez ich dzierżawę i przeznaczanie środków na cele inwestycyjne, jak również poprzez ich darowanie czy oddawanie w nieodpłatne korzystanie gminom ma niekiedy istotny wymiar społeczny, ponieważ zaspokaja wiele potrzeb lokalnych społeczności. Należy przy tym stwierdzić, że wartości i zasady większości przebadanych wspólnot gruntowych są zbieżne z cechami i funkcjami ekonomii społecznej. Można je bowiem wykorzystać do rozwiązywania współczesnych problemów rolników związanych z utrzymaniem się na rynku oraz podniesienia rozwoju i konkurencyjności ich gospodarstw rolnych. Funkcjonowanie wspólnot gruntowych, mając wpływ na rozwój gospodarczy lokalnych społeczności, może zatem

\footnotetext{
49 Zob. także http://www.wspolnotygruntowe.pl/wspolnoty-gruntowe/wspolnota-gruntowa-w-gasawach-rzadowych. html, (data dostępu: 28.07.2018 r.).

50 Zob. także http://www.wspolnotagruntowa-siewierz.pl/co_spolka robi_dla_siewierza (data dostępu: 28.07.2018 r.).

Zob. ankieta sporządzona przez przewodniczącego zarządu Wspólnoty Gruntowej wsi Strzałków.

52 Spośród funkcjonujących organizacji rolniczych, obok wspólnot gruntowych, do tego nurtu należy zaliczyć spółki wodne - powołane do eksploatacji i konserwacji urządzeń melioracyjnych (zob. A. Stelmachowski, Prawo rolne, Warszawa 2008, s. 287).
} 
prowadzić do poprawy sytuacji materialnej mieszkańców wsi i terenów wiejskich. Wspólnoty gruntowe jako forma zbiorowej zaradności mogą w końcu pomóc społecznościom wiejskim w utrzymaniu aktywności społecznej i gospodarczej ${ }^{53}$.

Rozważania w przedmiocie funkcji kulturowej wspólnoty gruntowej należy prowadzić przez pryzmat ich umiejscowienia w schemacie klasyfikacyjnym jako szczególnego rodzaju społeczności wiejskiej. Przyjęty w socjologii i etnografii model społeczności wiejskiej łączy bowiem w sobie następujące aspekty. Pierwszy z nich to wymiar ekologiczny - odnosi się do faktu zamieszkiwania przez pewną grupę pewnej przestrzeni niezaliczanej do obszaru miasta. Drugi wymiar - interakcyjny - oznacza, że członkowie tej grupy wchodzą ze sobą w różnego rodzaju relacje, zarówno na gruncie miejsca zamieszkania, jak też wykonywanej pracy. Trzeci wymiar - strukturalno-społeczny - sprowadza się do założenia, iż przynajmniej część tych relacji przebiega w ramach trwale uformowanych instytucji formalnych i nieformalnych, które tworzą dające się wydzielić analityczne układy, w rzeczywistości silnie ze sobą zespolone, np. ekonomiczny, społeczny, kulturowy, przy czym układy te zaspokajają istotne dla życia członków tej grupy i dla całej grupy funkcje. Czwarty wymiar - świadomościowy - interpretuje się jako przekonania i postawy właściwe tej grupie, przynależne jej „,współczynniki humanistyczne”54.

Lokalizując społeczność wspólnoty gruntowej na określonym obszarze, który stanowi dla niej podstawowe miejsce życia oraz pracy, wskazać należy, że jest to przestrzeń zarówno w sensie naturalnego ukształtowania krajobrazu, jak i realizowanej zabudowy. Kształt tej przestrzeni określają zarówno czynniki przyrodnicze, warunki zastane - stanowiące świadectwo ingerencji człowieka, jak też bieżąca działalność uczestników wspólnoty ${ }^{55}$. Istotnym aspektem ekologicznego wymiaru funkcji kulturowej wspólnoty jest również nadanie znaczenia społecznego poszczególnym miejscom wyróżnianym w lokalnej przestrzeni. Wspólnota dzieli się bowiem na fragmenty o większym i mniejszym znaczeniu dla społeczności, miejsca nobilitujące, bądź świadczące o degradacji jej członków ${ }^{56}$.

W aspekcie interakcyjnym oraz związanym z nim strukturalno-funkcjonalnym charakteryzowanej instytucji wskazać należy, że każda wspólnota gruntowa ma swoją, nieraz wielowiekową historię. Dzieje oraz wydarzenia we wspólnocie przekazywane są w drodze ustnej tradycji, ale też w zinstytucjonalizowanej formie „,izby pamiątek”. Członkowie większości przebadanych wspólnot gruntowych iden-

\footnotetext{
53 Wspólnoty gruntowe należy zatem uznać za należące do tego sektora gospodarki, w którym organizacje są zorientowane na społeczną użyteczność, a wypracowywana przez nie nadwyżka służy realizacji celu społecznego. Misja wspólnot wynika z autonomii zarządzania, demokratycznego decydowania oraz lokalnego zakorzenienia. Zob. I. Bukraba-Rylska, Socjologia wsi polskiej, Warszawa 2008, s. 436; zob. także B. Gałęski, Socjologia wsi. Pojęcia podstawowe, Warszawa 1966; A. Hillary, Definition of Community: Areas of Agreement, „Rural Sociology" 1955, t. XX, s. 119.

55 Zob. M. Chilczuk, Osadnictwo wiejskie Polski. Formy i układy przestrzenne, Warszawa 1970.

56 Zob. I. Bukraba-Rylska, Socjologia wsi..., op. cit, s. 449-450.
} 
tyfikują się ze wspólnotą dzięki doświadczeniom i przeżyciom, jakie zgromadzili w związku z urodzeniem się i przebywaniem w okresie dzieciństwa w swoim środowisku lokalnym. Mają poczucie związków ze swoją wspólnotą dzięki stosunkom pokrewieństwa, powinowactwa, sąsiedztwa czy znajomości, jakie łączyły ich lub nadal łączą z osobami i rodzinami uczestniczącymi w tej samej wspólnocie ${ }^{57}$. Wchodzą ponadto w rozmaite relacje o charakterze ekonomicznym i społecznym, które wynikają często ze wskazanych powyżej więzi naturalnych, sąsiedzkiego współżycia i uczestniczenia w życiu wspólnoty, podlegania różnego rodzaju instytucjom narzuconym z zewnątrz, w tym ze strony organów spółki wspólnoty gruntowej ${ }^{58}$, jak również faktu wspólnego korzystania z gruntów wspólnotowych. Wskazać przy tym należy, że przedstawiane relacje, chociaż są często regulowane w znacznym stopniu zwyczajem i egzekwowane pod presją środowiska, znajdują wyraz w działaniach formalnych, podporządkowanych decyzjom organów wskazanej powyżej spółki, jak też regulowanych przepisami prawa oraz decyzjami organów administracji ${ }^{59}$.

Czwarty, ostatni z wymienionych wymiarów wiejskiego charakteru społeczności wspólnotowej odnosi się do sfery świadomościowej. Konstytuują ją takie elementy, jak: określony kształt kultury danego środowiska, mit grupowej wartości, który podkreśla wyjątkowość własnej grupy i stanowi uzasadnienie dla odmiennego traktowania „,swoich” i „obcych”, - zwane w socjologii patriotyzmem lokalnym. Wszystkie te aspekty łącznie składają się na silne poczucie swojskości i zarazem bardzo wyraźną świadomość odrębności na zewnątrz ${ }^{61}$.

I tak, w świetle ostatniej z powołanych cech wskazać należy, że wielu udziałowców jest świadomych bycia częścią instytucji, która nie tylko ma długą historię, ale także wspiera rozwój społeczności lokalnych. Przykładem niech będą dostarczone przez przewodniczącego Zarządu Wspólnoty Gruntowej we wsi Strzałków artykuły w „Dzienniku Łódzkim” o tytułach „Wspólnota wychodzi na prostą” oraz „Wizytówka Strzałkowa”. W drugim z przywołanych artykułów podkreśla się, że „społeczeństwo pozytywnie odbiera działalność, jaką prowadzi Wspólnota, jest zainteresowanie tym, co się dzieje oraz tym, co się będzie działo w najbliższym czasie. Na terenie nieruchomości nie znajdują się już bowiem dzikie wysypiska śmieci, lecz teren utrzymany jest $\mathrm{w}$ należytym porządku, a sami mieszkańcy dokładają starań, aby w takim porządku pozostał (...). Cały obiekt cieszy się dużą popularnością i zainteresowaniem zarówno wśród mieszkańców, jak i młodzieży, której udostępniane jest boisko. [Wspólnota gruntowa] ${ }^{62}$ staje się powoli wizytówką Strzałkowa". 
W przypadku wspólnot gruntowych, sfera świadomościowa funkcji kulturowej mocno związana jest $\mathrm{z}$ wymiarem historycznym charakteryzowanych instytucji. Jak zostało podniesione, ich geneza sięga epoki średniowiecza, a kształtowanie dokonywało się w rezultacie różnych historycznych przemian społeczno-gospodarczych. Powyższe oznacza tym samym, że każda ze wspólnot gruntowych ma własną, unikalną historię, identyfikującą kulturowo daną społeczność lokalną. Na przykłady takich wspólnot zwraca uwagę profesor Andrzej Stelmachowski w publikacji pt. Relikty dawnej własności wiejskiej, przywołując między innymi wspólnotę leśną „Piwniczna Szyja”, obejmującą lasy okalające wieś Kosarzyska ${ }^{63}$, położoną na Śląsku Opolskim wspólnotę Kadłub Wolny ${ }^{64}$ czy też leśną wspólnotę gruntową we wsi Komańcza $^{65}$. Kwestia powołanego powyżej wymiaru historycznego wspólnot gruntowych była również podnoszona kilkakrotnie przez przedstawicieli wspólnot uczestniczących w przeprowadzonych badaniach empirycznych ${ }^{66}$.

W ślad za zastrzeżeniem poczynionym na wstępie niniejszego artykułu, wyniki przeprowadzonej analizy odnosić należy wyłącznie do sytuacji poszczególnych wspólnot funkcjonujących w zgodzie z przepisami ustawy z dnia 29 czerwca $1963 \mathrm{r}$. Jak zostało bowiem zauważone, fakt otrzymania niedużej liczby odpowiedzi w trakcie przeprowadzonych badań empirycznych oznacza $w$ istocie, że zdecydowana większość wspólnot prawdopodobnie nie wykazała zainteresowania badaniem, nie funkcjonuje, bądź jest „martwa”. Odnoszenie zatem otrzymanych wyników do sytuacji faktycznej wszystkich charakteryzowanych instytucji na obszarze kraju byłoby niemiarodajne i prowadziło do zbyt daleko idących wniosków. Jednocześnie, w zakresie wspólnot poddanych przedmiotowym badaniom empirycznym, wnioski z nich płynące należy postrzegać jako pozytywne. Przeprowadzona bowiem analiza wskazuje, że wraz z upływem ponad 55 lat obowiązywania ustawy o zagospodaro-

63 Użytkowana obecnie przez mieszkańców miasta Piwniczna, swoje pochodzenie zawdzięcza przywilejowi nadanemu w 1348 r. przez Kazimierza Wielkiego w ramach osadnictwa przygranicznego. Król, dążąc do zapewnienia stabilności stosunków przygranicznych z Węgrami, nadał osadnikom odpowiedni obszar ziemi na wspólną własność, tworząc osadę. Oryginalny tekst dokumentu nadania nie zachował się, jednak mieszkańcy powoływali się na dzieło Długosza, w którym znajduje się wzmianka o utworzeniu ich wspólnoty na podstawie nadania królewskiego. Zob. A. Stelmachowski, Relikty dawnej własności wiejskiej, „Rozprawy i studia. Księga pamiątkowa dedykowana Profesorowi Aleksandrowi Lichorowiczowi”, Kraków 2009, s. 242.

64 Wspólnota powstała w drodze wykupu gruntów z miejscowych dóbr rycerskich, zatwierdzonego dokumentem wystawionym przez cesarza Rudolfa III w 1603 r. Dokument był starannie przechowywany przez uprawnionych. O miejscu przechowania wiedziało tylko trzech z nich; w razie śmierci jednego, pozostali wyznaczali jego następcę. Umowa wykorzystywana była dwukrotnie w procesach sądowych w XX wieku i dwukrotnie przesądzała o korzystnym orzeczeniu na rzecz wspólnoty. Zob. A. Stelmachowski, Relikty..., op. cit., s. 243.

65 Wspólnota swój początek zawdzięcza aktowi nabycia na wspólną własność gruntów należących do hrabiego Potockiego, przez grupę tamtejszych chłopów, jeszcze przed akcją uwłaszczenia w 1848 r. W konsekwencji zdarzeń, jakich doświadczyli mieszkańcy Bieszczad w okresie II wojny światowej, polegających między innymi na przesiedleniach ludności łemkowskiej, pozostało jedynie siedmiu uprawnionych do udziału we wspólnocie. Uznali oni, że dla własnego bezpieczeństwa należy dokonać zmian i postanowili dopuścić do udziału we wspólnocie pozostałych stu dziewiętnastu gospodarzy (zob. A. Stelmachowski, Relikty..., op. cit., s. 243.).

66 Dla przykładu, w odpowiedzi na pytanie o wolę likwidacji Wspólnoty Gruntowej w Osadzie Bolimów przewodniczący zarządu spółki dla zagospodarowania tejże wspólnoty wskazał, iż „tereny, na których działamy, zostały nam nadane aktem królewskim w 1519 roku. Jest to długa historia, z której jesteśmy dumni. W naszej puszczy żyły ostatnie tury w Europe. Nie zamierzamy likwidować naszej wspólnoty gruntowej (zob. ankieta sporządzona przez przewodniczącego zarządu spółki dla zagospodarowania Wspólnoty Gruntowej w Osadzie Bolimów). 
waniu wspólnot gruntowych oraz zajścia znaczących zmian w zakresie założeń systemowych i gospodarczych państwa, ewolucji uległa także rola tych instytucji w rolnictwie. Wpisują się one we współczesną tendencję ekologizacji Wspólnej Polityki Rolnej, jak również pełnią istotne dla społeczności lokalnych funkcje gospodarczo-społeczne oraz kulturowe. Pomimo zatem niewielkiej skali odniesienia, powyższe okoliczności - w opinii autora - uzasadniają utrzymywanie charakteryzowanych instytucji w systemie prawa polskiego. Nie tylko bowiem pełnią one role społecznie korzystne, ale też mogą stanowić przykład skłaniający do podejmowania działalności przez wspólnoty martwe oraz te, które w świetle znowelizowanych przepisów prawa mogą zostać powołane do życia. 
FUNCTIONS OF COMMON LANDS IN THE LIGHT OF EMPIRICAL RESEARCH

Keywords: common land, joint ownership, common land's company

Common lands are special kind of institution of agricultural law, structurally similar to co-ownership in fractional parts. Its content contains the right to collectively possess the land by entities residing or having homestead in the locality of the common land. Common lands were subject to very different legal regulations whose axiology was justified by the moods of a given historical moment. The normative function of the current Act of 29 June 1963 on the development of common lands was justified by the assumptions of the agricultural policy of the period, i.e. indirect socialization. The transformation of the political system in Poland after 1989, followed by the accession of Poland to the European Union on May 1, 2004 under the Accession Treaty, resulted in the introduction of a number of changes in law, politics, economy and society that outdated the objectives that guided of the legislator in 1963. The purpose of this article is to confront the normative functions of land communities with real functions in the light of empirical research.

\section{Bibliografia:}

Adamowicz M., Wiejskie gospodarstwa domowe w obliczu problemów transformacji, integracji i globalizacji, Warszawa 2004.

Adamowicz M., Wielofunkcyjne gospodarstwa rolne jako podmiot w rozwoju wsi i rolnictwa, „Prace Naukowe SGGW" 2004, nr 33.

Allen R., Enclosure and the yeoman. The agricultural development of the south Midlands 1450-1850, Oxford 1992.

Bardach J., Leśnodorski B., Pietrzak M., Historia ustroju i prawa polskiego, Warszawa 2009.

Bujak F., Studia nad osadnictwem Małopolski, Kraków 1905.

Bukraba-Rylska I., Socjologia wsi polskiej, Warszawa 2008.

Buzek J., Administracja gospodarstwa społecznego, Warszawa 1913.

Chilczuk M., Osadnictwo wiejskie Polski. Formy i układy przestrzenne, Warszawa 1970.

Czechowski P., Prawo rolne, Warszawa 2015.

Dajczak W., Giaro T., Longchamps de Bérier F., Prawo rzymskie, Warszawa 2015.

De Moor M., Warde P., Shaw-Taylor L., The management of common land in north west Europe, c. 1500-1850, Turnhout 2002.

Dobrowolski K., Studia nad życiem społecznym i kulturą, Wrocław-Warszawa 1966.

Gałęski A., Socjologia wsi. Pojęcia podstawowe, Warszawa 1966.

Hammond J.L., Hammond B., The village labourer 1760-1832, Gloucester 1911.

Hillary A., Definition of Community: Areas of Agreement, „Rural Sociology” 1955, t. XX.

Ignatowicz J., Stefaniuk K., Prawo rzeczowe, Warszawa 2009. 
Jeżowski P., Zarządzanie w sektorze publicznym-rozwój zrównoważony - metody wyceny, Warszawa 2002.

Jurcewicz A., Prawo i polityka rolna Unii Europejskiej, Warszawa 2010.

Lipińska I., Rola i funkcjonowanie wspólnot gruntowych we współczesnych warunkach gospodarczych, „Problemy Rolnictwa Światowego” 2010, t. 10 (XXV), z. 4.

Lipińska I., Z prawnej problematyki wspólnot gruntowych, „Studia Iuridica Agraria” 2011, t. X.

Ludkiewicz Z., Polityka agrarna, Poznań-Warszawa 1921.

Łepkowski T., Polska - narodziny nowoczesnego narodu, 1764-1870, Warszawa 1967.

Marciniuk K., Kilka uwag do założeń projektu ustawy o zmianie ustawy o zagospodarowaniu wspólnot gruntowych, „Studia Iuridica Agraria” 2012, t. X.

Milanowska D., Wybrane metody systematyzacji prawodawstwa Unii Europejskiej z uwzględnieniem aktów prawnych z zakresu prawa rolnego, „Studia Iuridica Agraria” 2013, t. XI.

Neeson J.M., Commoners: common right, enclosure and social change in England 1700-1820, Cambridge 1993.

North D.C., Thomas R.P., The first economic revolution, „Economic History Review” 1977, vol. 30.

Ossowski S., Analiza socjologiczna pojęcia ojczyzny, „Dzieła” 1967, t. 3.

Poskrobko B., Ekonomia zrównoważonego rozwoju w świetle kanonów nauki, Białystok 2011.

Prutis S., Ochrona środowiska za pomocą instrumentów prawno-finansowych Wspólnej Polityki Rolnej, „Studia Iuridica Agraria” 2015, t. XIII.

Ptaszyk M., Spółki do zagospodarowania wspólnot gruntowych - sytuacja prawna, funkcjonowanie, perspektywy, Kraków 1989.

Roszkowska-Mądra B., Kategorie ekonomii zrównoważonego rozwoju na poziomie gospodarstwa rolnego, „Gospodarka Narodowa” 2009, nr 10.

Rybicki P., Struktura społecznego świata: studia z teorii społecznej, Warszawa 1979.

Stelmachowski A., Prawo rolne, Warszawa 1987.

Stelmachowski A., Prawo rolne, Warszawa 2008.

Stelmachowski A., Relikty dawnej własności wiejskiej, „Rozprawy i studia. Księga pamiątkowa dedykowana Profesorowi Aleksandrowi Lichorowiczowi”, Kraków 2009.

Strzelczyk R., Prawo Nieruchomości, Warszawa 2017.

Szachułowicz J., Spółki grup producentów rolnych spółkami użyteczności publicznej, „Studia Iuridica Agraria" 2005, t. V.

Tawney R., The Agrarian problem in the sixteenth century, London 1912.

Thompson E.P., The making of the English working class, London 1968.

Thompson E.P., Customs in common, London 1992.

Turowski J., Socjologia wsi i rolnictwa, Lublin 1995. 